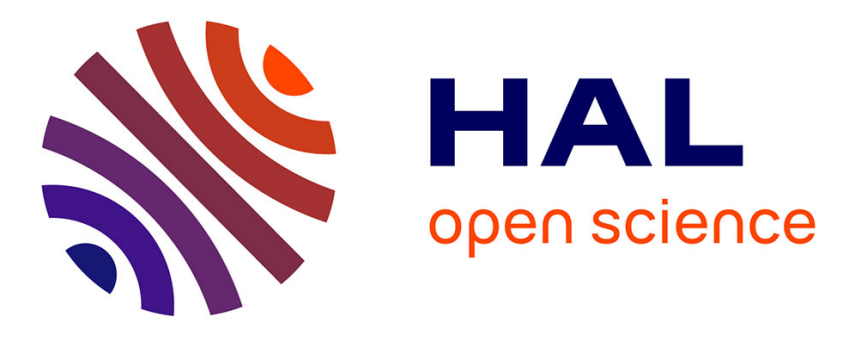

\title{
Methodological progress in on-farm regional agronomic diagnosis. A review
}

\author{
Thierry Doré, Cathy Clermont-Dauphin, Yves Crozat, Christophe David, \\ Marie-Hélène Jeuffroy, Chantal C. Loyce, David Makowski, Eric Malézieux, \\ Jean-Marc Meynard, Muriel Valantin-Morison
}

\section{To cite this version:}

Thierry Doré, Cathy Clermont-Dauphin, Yves Crozat, Christophe David, Marie-Hélène Jeuffroy, et al.. Methodological progress in on-farm regional agronomic diagnosis. A review. Agronomy for Sustainable Development, 2008, 28 (1), pp.151-161. 10.1051/agro:2007031 . hal-00886410

\section{HAL Id: hal-00886410 https://hal.science/hal-00886410}

Submitted on 1 Jan 2008

HAL is a multi-disciplinary open access archive for the deposit and dissemination of scientific research documents, whether they are published or not. The documents may come from teaching and research institutions in France or abroad, or from public or private research centers.
L'archive ouverte pluridisciplinaire HAL, est destinée au dépôt et à la diffusion de documents scientifiques de niveau recherche, publiés ou non, émanant des établissements d'enseignement et de recherche français ou étrangers, des laboratoires publics ou privés. 


\title{
Methodological progress in on-farm regional agronomic diagnosis. A review
}

\author{
Thierry Doré ${ }^{1}$, Cathy Clermont-Dauphin ${ }^{2}$, Yves CrozaT ${ }^{3}$, Christophe DAVID ${ }^{4}$, Marie-Hélène JeUfFroY ${ }^{5}$, \\ Chantal LOYCE ${ }^{1}$, David MAKOWSKI ${ }^{5}$, Eric MALÉZIEUX ${ }^{6}$, Jean-Marc MEYNARD ${ }^{7}$, Muriel VALANTIN-MORISON ${ }^{5 *}$ \\ ${ }^{1}$ AgroParisTech, UMR211 INRA/AgroParisTech, BP 01, 78850 Thiverval-Grignon, France \\ ${ }^{2}$ IRD, DRV-UR176 SOLUTIONS, Land Development Department, Office of Science for Land Development, Paholyothin Road, Chatuchak, \\ Bangkok 10900, Thailand \\ ${ }^{3}$ Laboratoire d'Écophysiologie Végétale et Agroécologie, Groupe ESA, 55 rue Rabelais, BP 748, 49007 Angers Cedex 01, France \\ ${ }^{4}$ ISARA Lyon, Agrapole, 69364 Lyon 07, France \\ ${ }^{5}$ INRA, UMR211 INRA/AgroParisTech, BP 01, 78850 Thiverval-Grignon, France \\ ${ }^{6}$ CIRAD, UMR SYSTEM, 34060 Montpellier, France \\ ${ }^{7}$ INRA, Département SAD, Bâtiment EGER, 78850 Thiverval-Grignon, France
}

(Accepted 8 June 2007)

\begin{abstract}
The development of sustainable cropping systems is a key priority for agronomists and crop scientists. A first step involves understanding the relationship between cropping system performance and farmers' practices. To complete this step, a methodological framework entitled Regional Agronomic Diagnosis (RAD) has been developed. During the last ten years, the scope of the regional agronomic diagnosis has been enlarged to include several factors describing crop quality and the environmental impact of cropping systems. Regional agronomic diagnosis has led to several major advances such as (1) the assessment of the effect of preceding crop and soil structure on malting barley quality in France and (2) the assessment of the effects of ploughing, nematicide use and fertilisers on soil properties in intensive banana plantations in the West Indies. Improvements have also been gained in methodology, particularly by the selection of indicators for assessing the effects of crop management, soil and weather conditions, and data analysis. Finally, regional agronomic diagnosis has been integrated into more general approaches of agricultural development. We review here this methodological progress.
\end{abstract}

diagnosis / on-farm research / indicator / cropping system / agronomic performance / yield gap analysis / barley / nematicide / banana / soil

\section{INTRODUCTION}

An understanding of the effects of cropping systems on soil characteristics, plant growth and development, and biocoenosis is essential for the improvement of farming practices. Improvement may increase crop yield and quality and reduce the environmental impact of cropping systems, thereby contributing, to various extents, to sustainable development. Many studies on this topic have been carried out at research stations, in trials in which different factors are fixed and combined, to evaluate the effects of different experimental treatments on crop performance, quality or environmental value. However, on-farm research studies are also carried out in farmers' fields. Some of this on-farm research aims to assess the value of innovative cropping systems, as shown in case studies by Dejoux et al. (2003); Jackson et al. (2004); Blaise et al. (2005); Esilaba et al. (2005); Hasegawa et al. (2005). This evaluation is the final stage in a process starting with identification of the main factors limiting crop production. Other on-farm studies try to identify and to rank the cropping practices responsible, in interaction with the environment, for a large proportion of the

\footnotetext{
*Corresponding author: dore@agroparistech.fr
}

total variability in crop production, crop quality and environmental impact in a region. Such studies are not based on experimental trials. Instead, they are based on monitoring and series of measurements in a network of fields cultivated by farmers using current cropping practices. These on-farm studies are used for diagnostic purposes (Fig. 1), their results being used to define innovative cropping systems at the next step, the design step. These innovative cropping systems are then evaluated through on-farm trials or experiments at field stations, before being passed on to farmers. As pointed out by Lobelle and Ortiz-Monasterio (2006) for crop yield, "the identification of strategies to reduce the yield gap requires an understanding of its causes", hence the need for diagnosis.

Doré et al. (1997) proposed a methodological framework for carrying out such an agronomic diagnosis: regional agronomic diagnosis (RAD). Case studies based on RAD were reviewed by Doré et al. in 1997. These case studies demonstrated the relevance of RAD for identifying and ranking limiting factors for crop yield on the regional scale. Nitrogen deficiencies linked to soil compaction affecting pea yield in France, crop establishment affecting wheat yield in Tunisia, and plant losses due to rapid submersion and/or rat and crab damage and paddy water level affecting rice yield in Thailand 


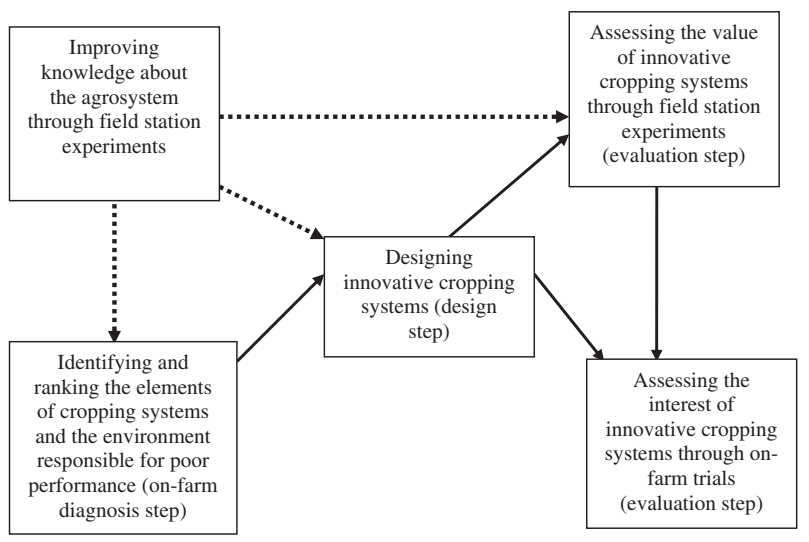

Figure 1. Relationships between the diagnosis step and the other steps of a general framework for cropping system improvement (continuous lines). The dashed lines indicate the use of analytical experiments carried out at research stations. Continuous lines indicate flows of information between steps.

provide examples of major limiting factors identified by RAD. Several aspects of RAD have been improved over the last ten years. In the past, diagnosis was generally applied to a single variable: crop yield. In several recent studies, this method has been applied to other variables relating to crop quality and environmental impact, with methodological consequences. New methods have also been proposed and used to analyse causal relationships between farmers' cropping systems and their agronomic or environmental performances. Finally, RAD has been better integrated into action-oriented agricultural projects for the dissemination of new knowledge to farmers. We will first summarise the main features of RAD and will then review these recent developments.

\section{OVERVIEW OF THE REGIONAL AGRONOMIC DIAGNOSIS APPROACH}

\subsection{Explaining the variability in cropping system performances on the regional scale}

RAD aims to determine why some fields in an agricultural region do not achieve the expected level of performance. This approach involves determining and accounting for variability in production (or production gaps) or environmental damage within a set of farmers' fields. Agricultural production depends on soil and climate characteristics, which vary between sites. In certain cases, this variability in production may be desirable. For instance, a spread of harvesting dates or a range of different size grades is often required for fresh vegetable production. However, variability in agricultural production may also limit performance on the regional scale (Le Bail and Meynard, 2003). So, whether we try to exploit it or to avoid it, many agronomic studies aim to understand the causes of this variability so that we can find the solutions best satisfying the target objectives.

Unsatisfactory situations occur on various scales. Yield may vary even within a single field, as shown by the numer- ous within-field yield maps now available. On a national or large regional scale, yield variation is just as frequent, and can largely be accounted for by differences in physical (soil type, weather) or socio-economic conditions, resulting in different local attainable and potential yields. Yield differences are also found on the intermediate scale of a common agricultural region (see the references cited in Doré et al., 1997; Wopereis et al., 1999; Van Keer, 2003). Regional agronomic diagnosis is applied to such small, homogeneous agricultural regions, defined on the basis of common climatic and soil characteristics and socio-economic features, including agri-food and food chains. Residual variability in soil and climatic characteristics in this agricultural region may account for some variation in performance (e.g. crop yield), but many studies have demonstrated that agricultural practices play a critical role (Boiffin et al., 1981; Aubry et al., 1994; Leterme et al., 1994; Affholder et al., 2003; Le Bail and Meynard, 2003; David et al., 2005a; Lobell and Ortiz-Monasterio, 2006).

\subsection{Applying a functional analysis to a set of farmers' fields}

Different elements of the cropping system, such as previous crop, genotype, crop protection management, date and mode of soil tillage, sowing date and density, and fertilisation strategy interact with the environment to determine crop yield. The identification by RAD of the element or combination of elements potentially responsible for the range of variation in crop yield observed on a regional scale requires the disentangling of complex relationships, and this must be tackled in the real situation of farmers' fields. Indeed, it would be difficult to reproduce the full range of diversity of combinations of physical environment and farming practices existing within a region in experimental trials (Sebillotte, 1974). It would also be impossible to choose the relevant factors for study in these experimental trials, as this identification of the most important factors is the intended result of the diagnosis step. For this reason, RAD studies are carried out mostly on a network of farm fields.

However, in practice, to achieve the objectives of RAD on a set of fields requires special attention to a major problem: different techniques are associated in various ways in an agricultural field, and farmers' practices may differ in several ways between fields. It is therefore difficult to determine, by simple comparisons of yield and farmers' practices, which techniques are responsible for yield variations. RAD involves functional analysis (see Doré et al., 1997) based on (1) an analysis of the relationships between yield variability and crop and/or environment characteristics during the growing period, and (2) an analysis of relationships between the characteristics of the soil-plant system and farmers' practices.

\subsection{Designing the field network}

The performance of RAD depends on the quality of the farmers' field network (Boiffin et al., 1981; Doré et al., 1997). 
The field network must represent the diversity of existing systems and environments (soil and climatic types) in the studied area. Some authors also include in this representative network rare or contrasting situations very different from the most common ones, or even innovative situations tested in experimental trials (see, for example, Sebillotte et al., 1978; Clermont-Dauphin et al., 2004b). These plots are useful for demonstrating the relationships between the variables to be explained (e.g. yield) and crop and environment characteristics during the crop cycle. However, caution is required when quantifying the effect of the different elements of cropping systems, as these additional contrasted fields may result in overestimation of the effect of some factors. Finally, some authors (Becker and Johnson, 1999, 2001; Becker et al., 2003) have excluded hypothetical and evident yield-limiting parameters in the network via superimposed and researcher-managed subplots in farmers' fields. Studies of the subplot network make it possible to assign part of the differences in yield to factors other than these evident parameters.

\subsection{Characterising crop and environment status}

The variables recorded for each field characterise the cropping system, in terms of the timing and rate of fertilisation, pest and disease control, sowing density and date and nature of the preceding crop, for example. They also include indicators providing information about the environment, such as temperature data, soil moisture content or soil-available nutrient content, and crop status, such as insect damage, vegetative biomass, rooting depth or leaf water potential. Some indicators are easy to access and reflect the entire growth cycle rather than just giving an instantaneous picture. These indicators include yield components, such as numbers of ears and grains, and mean grain weight in cereals. Indeed, the value of each yield component depends on the previously formed components and environmental factors during the formation of the yield component. The value of a given yield component can thus provide information about agronomic, edaphic and climatic conditions during its formation phase (see Fleury, 1991; Meynard and David, 1992; and Sect. 3.2.). In some cases, as in indeterminate legumes, it may be more appropriate and convenient to adopt a yield analysis based on measurements of vegetative growth. As suggested by Doré et al. (1997), many indicators used for RAD have been shown to be effective tools for analysing the functioning of agricultural fields (see, for example, Davidson and Ramsey, 2000; Clermont-Dauphin et al., 2004a; Haefele et al., 2006).

\subsection{Analysing the data}

Data are analysed in two steps: on a field scale and on a regional scale. On a field scale, the objective is to explain crop performance as a function of edaphic, climatic and agronomic factors. For example, Le Bail and Meynard (2003) observed alternating areas of tall and short plants in barley fields. The shorter zones corresponded to the drill lines situated behind the wheels of the tractor that sowed the crop. The simultaneous identification in the short-plant zones of (i) a compacted soil structure, (ii) crop nitrogen deficiency, and (iii) a small number of ears $/ \mathrm{m}^{2}$ suggested a nitrogen nutrition problem caused by soil compaction, due to soil tillage management in wet conditions in this field. The shift to the scale of a whole network of fields is of importance for two reasons. It makes it possible (a) to rank the various limiting factors according to their impact and frequency in a region, and (b) to validate hypotheses based on the analyses of individual fields. Indeed, if an environmental condition has been identified as responsible for the low yield of one field, all fields with an environment at least as unfavourable should have similarly low yields, unless an interaction with another variable can be implicated. This reasoning back-and-forth between the two scales - a major feature of this analysis - often requires data for more than one cropping season before the desired precision for the final diagnosis is reached (Meynard et al., 1981; Doré et al., 1998; ClermontDauphin et al., 2003, 2004a; David et al., 2005a). Finally, if the diagnosis identifies elements of the cropping system with effects highly dependent on an interaction with weather conditions, a specific study of the frequency of these interactions may be useful, although such studies are rarely carried out (see Boiffin and Meynard, 1982).

\section{METHODOLOGICAL IMPROVEMENTS}

\subsection{New variables of agronomic interest as subjects for regional agronomic diagnosis}

Food production has traditionally been the main function of agro-ecosystems (Costanza et al., 1997). However, cropping systems are now increasingly evaluated not simply on their production capacity, but also on their role in and impact on regional (e.g. surface- or ground-water quality) or global (e.g. participation in climate change via carbon storage or greenhouse gas emission) ecosystems. As a result, RAD has been applied to an increasing number of agronomic and environmental variables. These new applications led to several methodological developments, summarised below.

\section{Productive function}

In the past, the main variable studied in RAD was crop yield, defined as the quantity of useful biomass harvested annually per hectare. Recently, RAD has also been applied to variables characterising the quality of the harvested product, such as the grain protein content of malting barley (Le Bail and Meynard, 2003). This approach can also be extended to other quality criteria, such as the size or visual appearance of the harvested organs, or undesirable compound (pesticide residues, mycotoxins, heavy metals, etc.) content. These different objectives clearly require the development of diagnostic indicators complementary to those used for yield. In 
grapevine, for example, the quality of the grapes for winemaking is strictly dependent on water stress, and an indicator has been developed to evaluate the moisture regime of the vineyard (Pellegrino et al., 2006).

The effects of pests on crop product quality have led to specific studies, such as those on fungal diseases of bananas (Chillet et al., 2000) and pineapple (Marie et al., 2000). RAD may be used to evaluate the impact of certain pests or pest profiles (a combination of pathogens, herbivores and weeds) on crop performance (Valantin-Morison et al., 2007). Establishing the damage function, describing and quantifying the loss of yield or quality due to pests may indeed be an objective in itself.

\section{Non-productive functions}

Environmental concerns have increased in importance over the last 20 years, resulting in a need for new methods for measuring and evaluating relationships between agriculture and the environment (Boiffin et al., 2001). RAD is particularly suitable for empirical analysis of the impact of cropping systems on the environment in a given region. Nutrient balance (see, for example, Corre-Hellou and Crozat, 2005) and biological regulation (e.g. allelopathy, as in Sène et al., 2001) have already been the subject of specific regional diagnoses based on the same methodological framework as used for analyses of productive functions. Analyses of the variability in fertiliser efficiency on a maize/bean intercrop with low inputs in a small upland region of Haiti (Clermont-Dauphin et al., 2003) provides an example of the use of RAD to improve both production and soil fertility management. Clermont-Dauphin et al. (2004b) analysed the relationships between intensive management practices in a banana plantation and soil fertility characteristics, such as the organic matter content of soils, microbial respiration, nematode populations and earthworm biomass, in a field network in the French West Indies. Corbeels et al. (2006) evaluated soil carbon storage potential for different cropping systems with and without mulch in the Brazilian cerrados.

\section{Methodological consequences}

The RAD approach to evaluating new productive and nonproductive functions appears to be very similar to that described above for yield. However, some differences should be emphasised. Firstly, available knowledge concerning environmental processes is often less complete or detailed than that for the mechanisms involved in yield formation. Measurement of the environmental variable at field level often constitutes a major obstacle. For example, measurements of the emissions of greenhouse gases, such as nitrous oxide $\left(\mathrm{N}_{2} \mathrm{O}\right)$ or methane $\left(\mathrm{CH}_{4}\right)$ in the field remain difficult and costly, and improvements would be required before RAD could be attempted. A lack of knowledge concerning the processes involved also causes problems with analysis of the observed variation, particularly as environmental functions require a change of scale

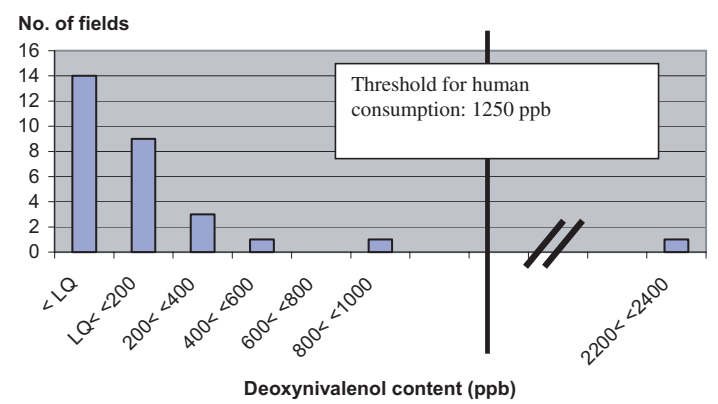

Figure 2. Example of a log-normal distribution of deoxynivalenol content in organic wheat grain in an area in France (LQ = limit of quantification). From Champeil (2004).

for the analysis. In some cases, it is difficult to distinguish clearly between the effects of crop management and the effects of landscape structure. Finally, the layout of fields in the area studied constitutes another methodological difficulty, as the impact of cropping systems on many environmental variables depends on the spatial location of the field in the territory considered. This is the case for erosion (role of slope and of the position of the field within the catchment area) and biodiversity (border effects, mosaic effects, etc.). In this context, the classical methodology of RAD, which does not take into account the position of the field in the landscape, requires adaptation. Valantin-Morison et al. (2007), in their study of the effect of cropping systems on insect populations and damage in organic oilseed rape, showed that explanatory variables characterising the spatial environment of the fields should be incorporated into the analysis.

Another methodological difficulty stems from the regional distribution of the values taken by the studied variable and sometimes from the existence of a threshold splitting the data into two subgroups, potentially calling into question the very definition of the aim of diagnosis. In most situations, the statistical distribution of the yield values obtained for a network of farm fields is approximately normal. However, in some cases, the distribution of yield or quality attributes may follow a log-normal law, as reported by de Bie (2004) for mango yields in northern Thailand, and by Champeil (2004, Fig. 2) for the Fusarium mycotoxin content of organic wheat grains. In cases of log-normal distributions, which are probably more frequently observed if quality criteria are considered, there are large numbers of fields with low or null values. These fields are of little use for establishing a hierarchy of characteristics of cropping systems determining variability. This is particularly true if, as is often the case for quality criteria, there is a standard threshold separating the sample of studied fields into subgroups. In one analysis of mycotoxin contamination in wheat (Champeil, 2004), the threshold concerned the maximal value of contamination, above which the crop becomes difficult to sell. Given the observed distribution (Fig. 2), the aim of the diagnosis becomes identifying the main effects of cropping systems accounting for the very high levels of contamination of certain fields. The products of these fields, when mixed in silos with those from fields with lower levels of contamination, 
are likely to increase considerably the toxin concentration of the average batch, making it unsaleable.

\subsection{Data analysis methods}

It is not easy to interpret data from field networks. Some progress has been made in this area in recent years, in three main areas: the estimation of potential yields, the choice of indicators and the establishment of relationships between yield and limiting factors. These methodological developments mostly concern diagnosis for yield variations. Nevertheless, the second and third aspects are also relevant to diagnosis for crop quality and environmental impacts.

\section{Estimation of potential yield and potential yield components}

Estimates of potential yields (limited by solar radiation and temperature only) or potential yield components can be used as yardsticks for assessing the results obtained in field networks (Meynard and David, 1992). They make "yield-gap analysis" possible within the RAD, just as this analysis of the difference between actual and potential yields is carried out in different environments and on different scales in various ways: on-farm, at research stations, or sometimes exclusively through modelling (e.g. Van Ittersum and Rabbinge, 1997; Mussgnug et al., 2006). Various criteria, such as yield shortfall in t.ha ${ }^{-1}$ (Becker and Johnson, 1999), yield shortfall in \% (David et al., 2005a) or indices calculated from two successive yield components obtained at different growth stages (Wey et al., 1998), can be used to quantify the effect of limiting factors.

Potential yield values are frequently estimated from crop models (Van Ittersum et al., 2003). For example, ORYZAS has been used for diagnosis on irrigated rice systems in the Sahel and savannah regions of West Africa (Wopereis et al., 1999), and LINTUL-POTATO has been used for potato production in Argentina (Caldiz et al., 2002). The drawbacks of this approach are that (i) crop models require a large number of input variables and (ii) crop model predictions may be inaccurate. It is therefore necessary to assess the accuracy of crop models before using them in practice, and adaptation of the model to the area studied may even be required. Another approach involves estimating potential yield (or yield component) values from experimental data (Mercau et al., 2001). One way to do this is to use the most extreme yield value within the dataset. Brancourt-Hulmel et al. (1999) used the mean of the most extreme values obtained for $n$ subsamples of the dataset, using a bootstrap procedure. However, this approach does not take measurement error into account and is therefore likely to overestimate the true potential yield. The variance of this estimator may also be very high due to sampling variability. A second approach involves defining a boundary line for a particular quantile and using this boundary line to determine potential yield values for different environments (Johnson et al., 2003). Makowski et al. (2007) suggested defining a quantile value as a function of the probability distributions for measurement error and limiting factor effect.

\section{Choice of relevant indicators}

It remains important to improve the precision and specificity of indicators, as defined above, without complicating their collection or affecting their robustness. Ideal indicators of limiting factors should generally display (i) high specificity (varying only with the limiting factor considered), (ii) "memory" (making it possible to diagnose past deficiencies), (iii) simple monitoring and (iv) robustness (large validity domain) (Meynard et al., 1997). Several studies in the last decade have aimed to improve indicator quality, and some such studies are still underway.

It is often useful to express the characteristics of the crop and the environment in the form of differences with respect to standard values. The standards may be (i) taken from previous publications (e.g. the critical curve for nitrogen content in aerial biomass published by Lemaire and Gastal, 1997), (ii) defined during trials in the same environment (e.g. the rice yield potential used by Van Asten, 2003), or (iii) simulated using existing models (see Meynard and David, 1992; Affholder and Scopel, 2001). In certain cases, in which the characteristics of the plants or environment are difficult to measure, models can be used to evaluate them. For example, Poussin et al. (2003) used the RIDEV model to estimate spikelet sterility for rice farmers' fields.

Some indicators based on crop attributes are not very robust. For instance, the delay in flowering proposed by Homma et al. (2004) as an indicator of water stress for a local rice cultivar in north-east Thailand, although more sensitive to soil moisture variations than the more commonly used "number of days of submersion" (Sharma Pradeep et al., 1995; Savary et al., 2005; Haefele et al., 2006), is only valid for the genotype studied. A similar problem applies to yield components. Thus, if several cultivars are used within the RAD network of farmers' fields, it is better to compare the differences between actual and potential yield for a given component rather than actual yield components (David et al., 2005a). In this case, the availability of genotype references for the potential values of yield components is essential for the analysis.

In the specific case of intercropping systems, the yield of each plant is highly dependent on the climatic environment created by the neighbouring plants, which varies according to the plants considered. For instance, Lamanda et al. (2006) showed that, in coconut plantations intercropped with annual crops, the relative density of the two species varies both between fields and within a given field. A similar situation applies to monospecific systems with a heterogeneous withinfield phenology, such as perennial banana systems (Tixier et al., 2004). These structural heterogeneities complicate diagnosis in such scenarios, as the choice of relevant indicators of crop status is not straightforward. It is therefore advisable, in such cases, to use models taking these heterogeneities into account (such as that of Lamanda et al., 2006 and Tixier et al., 2004). 


\section{Methods for establishing quantitative relationships be- tween limiting factors, indicators and yield in a field net- work}

Identifying and ranking limiting factors is often based on the definition of a model relating growth, yield or yield components to limiting factors. In this approach, it is necessary (i) to define the mathematical function relating growth, yield or yield components to the limiting factors, (ii) to estimate the parameters of the model equations from data, and (iii) to choose a procedure for selecting the most influential limiting factors and excluding those with no significant effect. Various statistical methods can be used to achieve this end. The most popular involves the use of a linear model to estimate the parameters by least squares methods and to select the limiting factors by stepwise regression: see David et al. (2005a), Le Bail and Meynard (2003), and Mercau et al. (2001) for recent examples. The main advantage of stepwise regression is that the various limiting factors are ranked according to their contribution to overall yield variability. However, this method can account for only a fraction of the complexity of the cropping system: few, if any, interactions between limiting factors are considered and the limiting factors are assumed to be linearly related to growth or yield components and to be additive, which is not always the case, as shown by Lecomte (2005) through an agronomic diagnosis on a trial network.

Other statistical methods can be used. Principal component analysis with instrumental variables (PCAIV, Lebreton et al., 1991) was used by Van Keer (2003) to identify limiting factors for upland rice yields in farmers' fields in northern Thailand. PCAIV allows the simultaneous analysis of two multivariate data matrices (for upland rice yield components in Van Keer's study) and an independent matrix including all the measured crop environmental and management variables. Finally, Cade et al. (1999) suggested using quantile regression techniques to analyse the relationships between plant characteristics and one or several limiting factors, but this method has not yet been used in RAD. Whatever the statistical method used, one of the major concerns is that the final estimation and interpretation of parameter values and model predictions are generally based only on the selected model. Uncertainty in the selection of the model and in parameter estimation is basically ignored once a final set of variables has been identified (Draper, 1995; Chatfield, 1995). However, this selection process may result in highly unstable non-robust results. More attention should be paid to this problem in the future.

Affholder et al. (2003) proposed an alternative method based on the use of a crop model to identify the causes of differences between potential and actual yields for maize production in central Brazil. This method involved generating a virtual experiment for each field situation, to estimate the extent to which yield is affected by a given constraint considered by the model. According to Lecomte (2005), if a limiting factor is present in all the fields of a network and published studies provide no threshold value above which yield is affected, the only way to identify and quantify the effect of that factor is to use a model. However, Affholder et al. (2003) pointed out that the main problem is building a model that can take into account the exhaustive list of limiting factors likely to occur in the study area.

\subsection{Connecting RAD to other research and development (R\&D) actions}

\section{Implications for the RAD framework}

The major aim of RAD is to identify and rank the elements of cropping systems responsible for variations in crop performance. It is often the first step in a research and development (R\&D) project aiming to improve cropping systems or farming systems on the regional scale. In such cases, RAD must be coupled with methods developed to provide an understanding of farm variability on the regional scale (see, for example, Rapey et al., 2001; Maton et al., 2005). This approach makes it possible to target technical options and to adapt dissemination to diverse farming systems. For example, David et al. (2005a) have been running a research and development project in south-eastern France since 1998, to improve agronomic conditions in organic cereal farming systems. Indeed, they selected organic wheat fields for RAD based on criteria designed to represent the diversity of organic farm types and of agronomic, edaphic and climatic conditions. The farm network was selected on the following criteria: (i) the main characteristics of the farming system: mixed vs. arable, (ii) the significance ( $\%$ area and $\%$ profit) of the organic cereal sector within the farm, from 5 to $80 \%$, and (iii) the time period over which the farm had been managed organically. The field network was selected from the farm network on the following criteria: (i) crop rotation and preceding crop, and (ii) soil type. RAD identified the most limiting factors and facilitated adaptation for further experimental trials, followed by recommendations for the various farming systems. Another example is provided by the work of Trébuil et al. (1997), who took into account differences in land use between farmers when choosing the fields for their network.

\section{Value of combining $R A D$ with additional research work}

The recommendations resulting from RAD are only relevant if the improvements suggested by agronomists are compatible with the way in which the farmers make their technical decisions (Cerf and Sebillotte, 1988; Aubry et al., 1998; McCown, 2002). It is therefore useful to combine RAD with a good knowledge of farmers' decision rules before defining recommendations. For instance, Meynard $(1985,1986)$ identified nitrogen deficiencies at the beginning of stem elongation due to delays in fertiliser application as a major factor limiting wheat yield in northern France. He analysed the work schedules and showed that these delays were due to competition with sugar beet drilling. Changes in work organisation therefore provided the solution to the problem of $\mathrm{N}$ deficiency in wheat (Meynard, 1986). Mathieu (2005) recently carried out a similar combined analysis for sorghum transplanted in the dry season in northern Cameroon. RAD on sorghum yield 
identified stem borer attack, weed infestation and water stress as major factors affecting yield. A simultaneous analysis of farmers' decision rules for crop planting and weed control made it possible to produce references not only for alternative techniques to exclude limiting factors or to reduce their effect, but also concerning the compatibility of these techniques with farm management. This work therefore led to the construction of analytical tables defining adapted crop management, which can be used by agricultural advisors considering individual farmers' situations. This work could be extended to the linking of RAD results and social modelling through multi-agent models, making scenario testing, prognosis and extrapolations possible.

The rapid identification by RAD of major limiting factors makes it possible to initiate additional studies enlarging the impact of RAD, even before the RAD has been entirely completed. An example is provided by the work of David (2004), analysing low yields and protein contents in organic wheat. RAD rapidly showed that nitrogen deficiency largely accounted for poor performance. Researchers have developed solutions for improving fertiliser efficiency in the springtime (i.e. delaying and fractioning applications to improve the synchronisation of wheat nitrogen requirements with organic fertiliser mineralisation, and adapting $\mathrm{N}$ application to soil water availability) through the use of a crop model parameterised and evaluated in parallel with the RAD (David et al., 2005b). This model makes it possible to adjust the recommended nitrogen fertilisation strategies according to recent weather events, the characteristics of the field linked to its soil and cropping system, and the incidence of other limiting factors, such as weeds, pests and diseases. Clermont-Dauphin et al. (2003) also highlighted the value of combining RAD with agronomic model-building for decision-making tools: the diagnosis ranks the limiting factors included in the model, making it possible to suggest innovative cropping methods (design step). This may make it necessary to modify the diagnostic process, including some technical variants for each field in the network so as to provide references for modelling. For example, modelling of the response of field bean crops to fertiliser in Haiti led to double diagnosis on farmers' fields, which were typically unfertilised, in the presence and absence of fertiliser (Clermont-Dauphin et al., 2003, 2004a).

\section{Exchanges with farmers in $R A D$}

The use of RAD in R\&D operations leads to exchanges with farmers and their advisors. It is important for researchers to integrate the farmers' knowledge into their hypotheses. During sampling of the field network, knowledge about cropping history and farm constraints is very useful. During data collection in the field, farmers' observations have, in some cases, led to the measurement of additional variables, which turned out to be valuable. Finally, when the researchers present the results to farmers, the observations of the farmers concerning their fields may assist researchers in their interpretation of the data. However, the many exchanges between researchers and farmers during RAD may give rise to unexpected complica- tions or valuable results. If, during the study, the RAD is accompanied by frequent consultation with the farmers, then the farmers may rapidly make use of some or all of the results, altering their practices in real time without waiting for the end of the RAD. As a result, the diagnosis is made on constantly changing cropping systems. This hinders global analysis of the pluriannual network, but transforms diagnosis for the last few years into an evaluation of technical proposals based on the first years' diagnosis. This process was observed in the study conducted by Le Bail and Meynard (2003) on the variation in yield and protein content in malting barley, in which the frequency of fields with a low yield and/or very high protein content fell markedly from the first year to the third year of study. This effect was attributed to a sharp reduction in the average amount of nitrogen fertiliser applied and to a change in the choice of the crop preceding barley in the rotation, which previous results of diagnosis had shown to be determining factors. In this case, solutions based on the results of the RAD were implemented by farmers before completion of the RAD.

\section{DISCUSSION}

The RAD method, as presented by Doré et al. (1997), and its extensions, as reviewed here, must be compared with other means of identifying and interpreting variations in yield (or other agronomic variables) on a regional scale - i.e. other diagnosis methods. The two most common alternative approaches are compared with RAD in Table I. The first ("oral diagnosis") involves asking farmers directly for their opinions concerning the reasons for these variations. This participative method involves a system-based diagnosis of the farmers' problems (Singh, 2004) and was used in the studies by Ingle et al. (2000) and Kataki et al. (2000). The major advantage of this method is its rapidity, because no measurements are required. After interviewing each farmer for just a few hours, this method can be used to attribute yield variations to specific effects of climate, soil and cropping systems. The main drawback of this system is that it depends on the farmers' expertise concerning agronomic processes. However, farmers may not always have sufficient technical knowledge to support their hypotheses, particularly if the cropping system is frequently modified. Yield losses due to soil compaction or soil-borne disease are, for example, commonly underestimated by farmers.

The second method ("correlative diagnosis") involves analysing correlations, in a large sample of fields, between the yield or yield-gap and cropping system, soil permanent characteristics and weather features. This method has been used in many studies involving various statistical tools. In some of these studies, such as those by Naidu and Hunsigi (2003) on sugarcane, parallels were observed between variations in yield and crop management practices (fertilisation practices in this case). Other studies, such as that by Hussain et al. (2003), compared different linear and non-linear models, whereas others, such as that by Casanova et al. (1999), compared different procedures (simple correlation, stepwise regression and the boundary line method). This diagnostic method, which, unlike RAD, does not use data on soil and crop status, is also 
Table I. A comparison of different on-farm diagnosis methods used to identify and rank the cropping practices responsible, in interaction with the environment, for the variability in crop production, crop quality and environmental impacts in a region.

\begin{tabular}{llll}
\hline & Regional agronomic diagnosis & "Oral diagnosis" & "Correlative diagnosis" \\
\hline $\begin{array}{l}\text { Analysis of the relationships } \\
\text { between farmers' practices and }\end{array}$ & $\begin{array}{l}\text { Systemic functional analysis of } \\
\text { the interactions between cropping } \\
\text { agronomic or environmental } \\
\text { pariables }\end{array}$ & $\begin{array}{l}\text { Farmers' expertise } \\
\text { ment }\end{array}$ & $\begin{array}{l}\text { Statistical correlations or factorial } \\
\text { analysis on yield and crop manage- } \\
\text { ment }\end{array}$ \\
$\begin{array}{l}\text { Criteria for designing field net- } \\
\text { works }\end{array}$ & $\begin{array}{l}\text { Representing the diversity of exi- } \\
\text { sting systems and environments }\end{array}$ & No specific network of fields & $\begin{array}{l}\text { Representing the diversity of existing } \\
\text { systems and environments }\end{array}$ \\
$\begin{array}{l}\text { Data to be recorded on each } \\
\text { field }\end{array}$ & $\begin{array}{l}\text { On each field of the network, } \\
\text { yield, farmers' practices, indica- } \\
\text { tors providing information about } \\
\text { the environment and crop status }\end{array}$ & & $\begin{array}{l}\text { On each field of the network, yields about limiting } \\
\text { and farmers' practices }\end{array}$ \\
Cost in time and money & High & Low & Low \\
\hline
\end{tabular}

very cheap and not particularly time-consuming, as the data required may be readily obtained from each farm by interview or mail (unless complete soil data are collected, as in the study by Casanova et al., 1999). The main drawback of this method is that significant correlations between two or more variables do not always reflect causal relationships. As the different aspects of cropping systems are closely associated, two variables are often found to be linked solely because both are linked to a third variable. Thus, even strong statistical correlations often reflect coincidence rather than a true functional relationship. Different solutions to this problem have been tested. Calviño and Sadras (2002) applied the method to wheat yield in Argentina. They did not consider actual yield, focusing instead on the difference between actual yield and the yield simulated with a water-stress model. This approach makes it possible to identify limiting factors other than those taken into account by the model. Lobell and Ortiz-Monasterio (2006) recently investigated the value of data concerning the spatial distribution of yields for analyses of the causes of yield variability at the landscape level. This promising approach combined stochastic crop models for translating assumed spatial patterns of soil and management conditions into spatial patterns of yield and Monte Carlo simulation, repeating the process for many different sets of conditions. It resulted in a modelled relationship between yield patterns and the relative importance of soil and management yield constraints. Based on this relationship, it was then possible to infer from observed yield patterns the proportion of yield variability accounted for by soil and management. However, this method depends on the quality of the crop model used and the availability of precise soil and climate data for a large number of fields. Nevertheless, this approach, making use, through the crop model, of information about the functional relationships between crop, soil and crop management, converges with that of RAD, which is becoming increasingly reliant on the use of models.

RAD seems to have an advantage over oral and correlative diagnosis in terms of the robustness of the relationships it reveals between cropping systems and agronomic variables, as the analysis is based on soil and crop status data from farmers' fields. It is not possible to exclude confounding factors entirely, but this method does at least reduce the risk of their occurrence. The major drawback of RAD remains its higher cost in terms of both time and money. RAD facilitates more effective use of current progress in agronomy than oral diagnosis, as illustrated by the frequent use of updated agronomic models at various stages of RAD.

RAD is based on an analysis of the functioning of the agroecosystem, making it a particularly powerful investigative tool. Agronomic diagnosis can also be performed on networks of field experiments, increasing understanding of the bases of the experimental results observed and improving assessments of the validity of the results (Meynard, 1985; Dejoux et al., 2003; Barbottin et al., 2005). For example, Barbottin et al. (2005), whilst characterising the performance of wheat cultivars in different environments, carried out a diagnosis on cultivar trials to analyse variability among genotypes in nitrogen remobilisation to grains. Separate analyses of typified environments with no limiting factors and environments subject to major abiotic or biotic limiting factors demonstrated the absence of a genotypic effect on remobilisation in favourable growing conditions, and a marked genotypic effect in the presence of airborne diseases.

Whatever the method used and the variable studied (yield, quality or any other variable), diagnosis work often makes it possible to define new research priorities when it reveals influences of cropping systems on little-studied variables of agronomic interest. Thus, at the International Rice Research Institute, diagnosis has made it possible not only to identify and to rank problems responsible for poor yields in peasant rainfed rice systems in Laos and Cambodia, but also to open up possibilities for initiating new research (Fujisaka, 1991; Fujisaka et al., 1994). Other examples can be found elsewhere in the world (Castella et al., 1997; Caldiz et al., 2002; Kudadjie et al., 2004). Diagnosis often helps to increase our knowledge of the agro-ecosystem and understanding of the diversity of the cropping systems present within a region, although these are not the primary objectives of this approach. Generally, diagnostic work demonstrates the heuristic value of carrying out part of the agronomic research directly in farmers' fields. This type of approach also efficiently increases the skills of the agronomist. 
In learning this approach, agronomists become familiar with an approach to the complex systems typical of real agriculture, the study of which cannot always be reduced to the "all other things being equal" comparisons of factorial experimentation. Moreover, diagnosis is based on an inductive method of reasoning, in which the aim is to work back to the causes of the observed results. This is at least as much a part of the duty of agronomists involved in R\&D as the more usual hypothetical and deductive reasoning.

\section{CONCLUSION}

Over the past ten years, the scope of RAD has been enlarged and its methods improved. Although time-consuming, RAD appears to be a useful complementary approach to research station experiments. Together with other on-farm programmes, RAD makes use of the data gathered in agricultural situations, whereas analytical experiments serve as an essential source of knowledge about the agrosystem. Efforts are continuing to improve certain aspects of the methods. Two questions in particular require additional detailed research. These questions concern the rules to be used for optimising the number and choice of fields for RAD and the possible use of remote-sensing data to reduce the cost of RAD and improve its efficacy.

Acknowledgements: We would like to thank the two anonymous referees and the Editor-in-Chief for their useful suggestions.

\section{REFERENCES}

Affholder F., Scopel E. (2001) Modèles de culture et diagnostic agronomique régional, in: Malézieux E., Trébuil G., Jaeger M. (Eds.), Modélisation des agroécosystèmes et aide à la décision, Coll. Repères, INRA-CIRAD, Montpellier, France, pp. 107-126.

Affholder F., Scopel E., Madeira Neto J., Capillon A. (2003) Diagnosis of the productivity gap using a crop model, Methodology and case study of small-scale maize production in central Brazil, Agronomie 23, 305-325.

Aubry C., Capillon A., Papy F. (1998) Modelling decision-making processes for annual crop management, Agr. Syst. 56, 45-65.

Aubry C., Latiri-Souli K., Doré T., Griner C. (1994) Diagnostic des facteurs limitants du rendement du blé dur en parcelles d'agriculteurs dans une petite région du semi-aride en Tunisie, Agronomie 14, 213-227.

Barbottin A., Lecomte C., Bouchard C., Jeuffroy M.H. (2005) Nitrogen remobilization during grain filling in wheat: genotypic and environmental effects, Crop Sci. 45, 1141-1150.

Becker M., Johnson D.E. (1999) Rice yield and productivity gaps in irrigated systems of forest zone of Côte d'Ivoire, Field Crop. Res. 60, 201-208.

Becker M., Johnson D.E. (2001) Cropping intensity effects on upland rice yield and sustainability in West Africa, Nutr. Cycl. Agroecosyst. 59, 107-117.

Becker M., Johnson D.E., Wopereis M.C.S., Sow A. (2003) Rice yield gaps in irrigated systems among an agro-ecological gradient in West Africa, J. Plant Nutr. Soil Sci. 166, 61-67.

de Bie C.A.J.M. (2004) The yield gap of mango in Phrao, Thailand, as investigated through comparative performance evaluation, Sci. Hort. $102,37-52$.
Blaise D., Majumdar G., Tekale K.U. (2005) On-farm evaluation of fertilizer application and conservation tillage on productivity of cotton + pigeonpea strip intercropping on rainfed Vertisols of central India, Soil Till. Res. 84, 108-117.

Boiffin J., Caneill J., Meynard J.M., Sebillotte M. (1981) Élaboration du rendement et fertilisation azotée du blé d'hiver en Champagne crayeuse. 1 : protocole et méthode d'étude d'un problème technique régional, Agronomie 1, 549-558.

Boiffin J., Malézieux E., Picard D. (2001) Cropping systems for the future, in: Nosberger J., Geiger H.H., Struik P.C. (Eds.), Crop Science: progress and prospects, CABI, pp. 261-280.

Boiffin J., Meynard J.M. (1982) Exemple d'approche régionale pour détecter les facteurs et les conditions limitants le rendement d'une culture : cas du blé d'hiver en Champagne crayeuse, Bull. Tech. Inf. 370-372, Ministère de l'agriculture, Paris, pp. 517-525.

Brancourt-Hulmel M., Lecomte C., Meynard J.-M. (1999) A diagnosis of yield-limiting factors on probe genotypes for characterizing environments in winter wheat trials, Crop Sci. 39, 1798-1808.

Cade B.S., Terrel J.W., Schroeder R.L. (1999) Estimating the effects of limiting factors with regression quantiles, Ecology 80, 311-323.

Caldiz D.O., Haverkort A.J., Struik P.C. (2002) Analysis of a complex crop production system in interdependent agro-ecological zones: a methodological approach for potatoes in Argentina, Agr. Syst. 73, 297-311.

Calviño P., Sadras V. (2002) On-farm assessment of constraints to wheat yield in the south-eastern Pampas, Field Crop. Res. 74, 1-11.

Casanova D., Goudriaan J., Bouma J., Epena G.F. (1999) Yield gap analysis in relation to soil properties in direct-seeded flooded rice, Geoderma 91, 191-216.

Castella J.C., Trébuil G., Crozat Y. (1997) Diagnosis on Thai agrarian systems for research prioritization to improve the sustainability and competitiveness of cotton production, Kasetsart J. Bangkok, Thailand, 31, 1-15.

Cerf M., Sebillotte M. (1988) Le concept de modèle général et la prise de décision dans la conduite d'une culture, C.R. Acad. Agric. Fr. 74, 71-80.

Champeil A. (2004) Contribution à la compréhension des effets des systèmes de culture sur l'infection des cultures de blé tendre d'hiver par la fusariose et la contamination des grains par les mycotoxines associées, Thèse de doctorat INA P-G, Paris, 132 p.

Chatfield C. (1995) Model uncertainty, data mining, and statistical inference, J. Roy. Stat. Soc. A 158, 419-466.

Chillet M., de Lapeyre de Bellaire L., Dorel M., Joas D., Dubois C., Marchal J., Perrier X. (2000) Evidence for the variation in susceptibility of bananas to wound anthracnose due to Colletotrichum musae and the influence of edaphic conditions, Sci. Hort. 86, 3347.

Clermont-Dauphin C., Meynard J.M. Cabidoche Y.M. (2003) Devising fertiliser recommendations for diverse cropping systems in a region: the case of low-input bean/maize intercropping in a tropical highland of Haiti, Agronomie 23, 673-681.

Clermont-Dauphin C., Cabidoche Y.M., Meynard J.M. (2004a) Diagnosis on low-input cropping systems in a tropical upland of Southern Haiti, Agr. Ecosyst. Environ. 105, 221-234.

Clermont-Dauphin C., Cabidoche Y.M., Meynard J.M. (2004b) Effects of intensive monocropping of bananas on properties of volcanic soils in the uplands of the French West Indies, Soil Use Manage. 20, 105-113.

Corbeels M., Scopel E., Cardoso A., Bernoux M., Douzt J.M., Siqueira M. (2006) Soil carbon storage potential of direct seeding mulchbased cropping systems in the cerrados of Brazil, Global Change Biol. 12, 1-15.

Corre-Hellou G., Crozat Y. (2005) $\mathrm{N}_{2}$ fixation and $\mathrm{N}$ supply in organic pea (Pisum sativum L.) cropping systems as affected by weeds and peaweevil, Eur. J. Agron. 22, 449-458. 
Costanza R., d'Arge R., de Groot R., Farber S., Grasso M., Hannon B., Limburg K., Naeem S., O’Neill R.V., Paruelo J., Raskin R.G., Sutton P., van den Belt M. (1997) The value of the world's ecosystem services and natural capital, Nature 387, 253-260.

David C. (2004) Le blé en agriculture biologique ; diagnostic agronomique et raisonnement de la fertilisation azotée de printemps, Thèse de doctorat INA P-G, Paris, 122 p.

David C., Jeuffroy M.H., Henning J., Meynard J.M. (2005a) Yield variation in organic winter wheat: a diagnostic study in the Southeast of France, Agron. Sustain. Dev. 25, 213-223.

David C., Jeuffroy M.H., Mangin M., Meynard J.M. (2005b) The assessment of Azodyn-Org model for managing nitrogen fertilization of organic winter wheat, Eur. J. Agron. 23, 225-242.

Davidson, J.A., Ramsey M.D. (2000) Pea yield decline syndrome in South Australia: the role of diseases and the impact of agronomic practices, Aust. J. Agr. Res. 51, 347-354.

Dejoux J.F., Meynard J.M., Reau R., Roche R., Saulas P. (2003) Evaluation of environmentally friendly crop management systems based on very early sowing dates for winter oilseed rape in France, Agronomie 23, 725-736.

Doré T., Sebillotte M., Meynard J.M. (1997) A diagnostic method for assessing regional variations in crop yield, Agr. Syst. 54, 169-188.

Doré T., Meynard J.M., Sebillotte M. (1998) The role of grain number, nitrogen nutrition and stem number in limiting pea crop (Pisum sativum) yields under agricultural conditions, Eur. J. Agron. 8, 2937.

Draper D. (1995) Assessment and propagation of model uncertainty, J. Roy. Stat. Soc. B 57, 45-97.

Esilaba A.O., Byalebeka J.B., Delve R.J., Okalebo J.R., Ssenyange D., Mbalule M., Ssali H. (2005) On farm testing of integrated nutrient management strategies in eastern Uganda, Agr. Syst. 86, 144-165.

Fleury A. (1991) Méthodologies de l'analyse de l'élaboration du rendement, in: Picard D. (Ed.), Physiologie et production du maïs, INRA, Paris, pp. 279-290.

Fujisaka S. (1991) A set of farmer-based diagnostic methods for setting post green revolution rice research priorities, Agr. Syst. 30, 191206.

Fujisaka S., Harrington L., Hobbs P. (1994) Rice-wheat in South Asia: systems and long-term priorities established through diagnostic research, Agr. Syst. 46, 169-187.

Haefele S.M., Naklang K., Harnpichitvitaya D., Jearakongman S., Skulkhu E., Romyen P., Phasopa S., Tabtim S., Suriya-Arunroj D., Khunthasuvon S. (2006) Factors affecting rice yield and fertilizer response in rainfed lowlands of northeast Thailand, Field Crop. Res. $98,39-51$.

Hasegawa H., Furukawa Y., Kimura S.D. (2005) On-farm assessment of organic amendments effects on nutrient status and nutrient use efficiency of organic rice fields in Northeastern Japan, Agr. Ecosyst. Environ. 108, 350-362.

Homma K., Horie T., Shiraiwa T., Sripodok S., Supapoj N. (2004) Delay of heading date as an index of water stress in rainfed rice in miniwatersheds in Northeast Thailand, Field Crop. Res. 88, 11-19.

Hussain I., Sakthivadivel R., Amarasinghe U., Mudasser M., Molden D. (2003) Land and water productivity of wheat in the western Indo-Gangetic plains of India and Pakistan: a comparative analysis, Research report 65, IWMI, Colombo, Sri Lanka.

Ingle P.O., Vaidya V.R., Makesar A.D. (2000) Reasons for yield gap in cotton in Vidarbha, Ann. Plant. Physiol. 14, 69-73.

Jackson L.E., Ramirez I., Yokota R., Fennimore S.A., Koike S.T., Henderson D.M., Chaney W.E., Calderón F.J., Klonsky K. (2004) On-farm assessment of organic matter and tillage management on vegetable yield, soil, weeds, pests, and economics in California, Agr. Ecosyst. Environ. 103, 443-463.
Johnson C.K., Mortensen D.A., Wienhold B.J., Shanahan J.F., Doran J.W. (2003) Site-specific management zones based on soil electrical conductivity in a semiarid cropping system, Agron. J. 95, 303-315.

Kataki P.K., Hobbs P., Adhikary B. (2000) The rice-wheat cropping system of South Asia: trends, constraints and productivity - A prologue, J. Crop Prod. 3, 1-26.

Kudadjie C.Y., Struik P.C., Richards P., Offei S.K. (2004) Assessing production constraints, management and use of sorghum diversity in north-east Ghana: a diagnostic study, Wageningen J. Life Sci. 52, 371-391.

Lamanda N., Malézieux E., Martin P. (2006) Structure and dynamics of coconut-based agroforestry systems in Melanesia: a case study from Vanuatu archipelago, in: Kumar B.M., Nair P.K.R. (Eds.), Advances in Agroforestry "Tropical homegardens, a time-tested example of sustainable agroforestry", Springer, pp. 105-120.

Le Bail M., Meynard J.M. (2003) Yield and protein concentration of spring malting barley: the effects of cropping systems in the Paris Basin (France), Agronomie 23, 13-27.

Lebreton J.D., Sabatier R., Banco G., Bacou A.M. (1991) Principal component and correspondence analyses with respect to instrumental variables: an overview of their role in studies of structure - activity and species - environment relationships, in: Devillers J., Karcher W. (Eds.), Applied Multivariate Analysis in SAR in Environmental Studies, ECSC, EEC, EAEC, pp. 85-114.

Lecomte C. (2005) L'évaluation expérimentale des innovations variétales : proposition d'outils d'analyse de l'interaction génotype - milieu adaptés à la diversité des besoins et des contraintes des acteurs de la filière semences, Thèse de doctorat, INA P-G, Paris, 174 p.

Lemaire G., Gastal F. (1997) N uptake and distribution in plant canopy, in: Lemaire G. (Ed.), Diagnosis of the Nitrogen Status in Crops, pp. 3-43.

Leterme P., Manichon H., Roger-Estrade J. (1994) Analyse intégrée des rendements du blé tendre et de leurs causes de variation dans un réseau de parcelles d'agriculteurs du Thymerais, Agronomie 14, 341-361.

Lobell D.B., Ortiz-Monasterio J.I. (2006) Regional importance of crop yield constraints: Linking simulation models and geostatistics to interpret spatial patterns, Ecol. Model. 196, 173-182.

Makowski D., Doré T., Monod H. (2007) Using quantile regression to analyse relationships between yield components, Agron. Sustain. Dev. (in press).

Marie F., Malézieux E., Marchal J., Perrier X. (2000) On farm approach of pineapple fruitlet core rot disease in Martinique, Acta Hort. 529, 261-264.

Mathieu B. (2005) Accompagner l'introduction d'une innovation en agriculture: cas de l'emploi des herbicides dans les systèmes de culture à muskuwaari, Thèse de doctorat, INA P-G, Paris, 376 p.

Maton L., Leenhardt D., Goulard M., Bergez J.E. (2005) Assessing the irrigation strategies over a wide geographical area from structural data about farming systems, Agr. Syst. 86, 293-311.

McCown R.L. (2002) Changing systems for supporting farmers' decisions: problems, paradigms and prospects, Agr. Syst. 74, 179-220.

Mercau J.L., Sadras V.O., Satorre E.H., Messina C., Balbi C., Uribelarrea M., Hall A.J. (2001) On-farm assessment of regional and seasonal variation in sunflower yield in Argentina, Agr. Syst. 67, 83-103.

Meynard J.M. (1985) Construction d'itinéraires techniques pour la conduite du blé d'hiver, Thèse de Docteur-Ingénieur, INA P-G, Paris.

Meynard J.M. (1986) Conduite de la sole de blé dans un calendrier de travail chargé, Éléments de solution, Bull. Tech. Inf. 412-413.

Meynard J.M., Boiffin J., Caneill J., Sebillotte M. (1981) Élaboration du rendement et fertilisation azotée du blé d'hiver en Champagne crayeuse. I. Types de réponse à la fumure azotée et application du bilan prévisionnel, Agronomie 1, 795-806.

Meynard J.M., Aubry C., Justes E., Le Bail M. (1997) Nitrogen diagnosis and decision support, in: Lemaire G. (Ed.), Diagnosis of the Nitrogen Status in Crops, pp. 147-161. 
Meynard J.M., David G. (1992) Diagnostic de l'élaboration du rendement des cultures, Cah. Agr. 1, 9-19.

Mussgnug F., Becker M., Son T.T., Buresh R.J., Vlek P.L.G. (2006) Yield gaps and nutrient balances in intensive, rice-based cropping systems on degraded soils in the Red River Delta of Vietnam, Field Crop. Res. 98, 127-140.

Naidu L.G.K., Hunsigi G. (2003) Sugarcane yield gap analysis, Kanabata, J. Agr. Sci. 16, 4-12.

Pellegrino A., Gozé E., Lebon E., Wéry J. (2006) A model-based diagnosis tool to evaluate the water stress experienced by grapevine in field sites, Eur. J. Agron. 25, 49-59.

Poussin J.C., Wopereis M.S.C., Debouzie D., Maeght J.L. (2003) Determinants of irrigated rice yield in the Senegal River Valley, Eur. J. Agron. 19, 341-356.

Rapey H., Lifran R., Valadier A. (2001) Identifying social, economic and technical determinants of silvopastoral practices in temperate uplands: results of a survey in the Massif Central region of France, Agr. Syst. 69, 119-135.

Savary S., Castilla N.P., Elazegui F.A., Teng P.S. (2005) Multiple effects of two drivers of agricultural change, labour shortage and water scarcity, on rice pest profiles in tropical Asia, Field Crop. Res. 91, 263-271.

Sebillotte M. (1974) Agronomie et agriculture, analyse des tâches de l'agronome, Cah. ORSTOM, série biologie 24, 3-25.

Sebillotte M., Boiffin J., Caneill J., Meynard J.M. (1978) Sécheresse et fertilisation azotée du blé d'hiver, Essai d'analyse de situations au champ par des composantes du rendement, Bull. l'AFES 3, 197213.

Sène M., Doré T., Gallet C. (2001) Relationships between biomass and phenolic production in grain sorghum grown under different conditions, Agron. J. 93, 49-54.

Sharma Pradeep K., Ingram K.T., Harnpichitvitaya D. (1995) Subsoil compaction to improve water use efficiency and yields of rainfed lowland rice in coarse-textured soils, Soil Till. Res. 36, 33-44.
Singh U.P. (2004) Farmers' participatory diagnosis of the flood-prone deepwater rice-cropping system in eastern India, Inter. Rice Res. Notes 29, 85-87.

Tixier P., Malézieux E., Dorel M. (2004) SIMBA-POP: a cohort population model for long-term simulation of banana crop harvest, Ecol. Model. 180, 407-417.

Trébuil G., Kam S.P., Turkelboom F., Shinawatra B. (1997) Systems diagnoses at field, farm and watershed levels in diversifying upland agroecosystems: towards comprehensive solutions to farmers' problems, in: Teng P.S. et al. (Eds.), Applications of Systems Approaches at the Farm and Regional Levels, Kluwer Academics, pp. $99-114$.

Valantin-Morison M., Meynard J.M., Doré T. (2007) Effects of crop management and surrounding field environment on insect incidence in organic winter oilseed rape (WOSR) in France, Crop Prot. (in press).

Van Asten P.J.A. (2003) Soil quality and rice productivity problems in Sahelian irrigation schemes, $\mathrm{PhD}$ thesis, Wageningen University, Wageningen, $143 \mathrm{p}$.

Van Ittersum M.K., Rabbinge R.R. (1997) Concepts in production ecology for analysis and quantification of agricultural input-output combinations, Field Crop. Res. 52, 197-208.

Van Ittersum M.K., Leffelaar P.A., van Keulen H., Kropff M.J., Bastiaans L., Goudriaan J. (2003) On approaches and applications of the Wageningen crop models, Eur. J. Agron. 18, 201-234.

Van Keer K. (2003) On-farm diagnosis of transitional upland rice swidden cropping systems in northern Thailand, $\mathrm{PhD}$ thesis, Katholieke Universiteit Leuven, $220 \mathrm{p}$.

Wey J., Oliver R., Manichon H., Siband P. (1998) Analysis of local limitations to maize yield under tropical conditions, Agronomie 18, $545-561$.

Wopereis M.S.C., Donovan C., Nebié B., Guindo D., N’Diaye M.K. (1999) Soil fertility management in irrigated rice systems in the Sahel and Savanna regions of West Africa. Part I. Agronomic analysis, Field Crop. Res. 61, 125-145. 